\title{
Triple-Junction Solar Cell Modelling Simulation using the PC1D Application
}

\author{
Fitria Hidayanti, Erna Kusuma Wati, Kiki Rezki Lestari, Fitri Rahmah, Alvin Liyanto \\ Engineering Physics Department, Universitas Nasional, Jakarta 12520 Indonesia \\ fitriahidayanti@gmail.com
}

\begin{abstract}
Solar cells are a renewable energy source that utilizes sunlight as a generator of electrical energy. Increasing the efficiency of solar cells can be done by stratifying several semiconductors that have different energy gaps or commonly referred to as multi-junctions. Simulations carried out using the PC1D application which is a freeware application. In this study, the semiconductor materials used in modelling triple-junction solar cells are $\mathrm{Al}_{0.3} \mathrm{Ga}_{0.7} \mathrm{As}$, GaAs and Ge. The results of this study, the output produced is in the form of Isc, Voc, Pmax, and IV Curve. The simulated solar cell produces Pmax for $\mathrm{Al}_{0.3} \mathrm{Ga}_{0.7} \mathrm{As}, \mathrm{GaAs}$ and $\mathrm{Ge}$ are respectively $14.6 \mathrm{~mW}, 10.71$ $\mathrm{mW}$, and $3.18 \mathrm{~mW}$. Each simulated semiconductor also has individual efficiencies of $10.68 \%, 7.83 \%$, and $2.33 \%$. The total efficiency of the solar cells is $20.84 \%$. The efficiency of the solar cell simulation results was $0.48 \%$ higher than the solar cells that have been studied previously.
\end{abstract}

Keywords: Triple-Junction, Solar Cell, Simulation, Renewable Energy, PC1D Application

\section{INTRODUCTION}

World energy demand continues to grow by $28 \%$, starting from 2015 to 2040. The greatest development of energy needs comes from countries that are not included in the Economic Cooperation and Development (ECD) organization, and the demand that occurs is due to economic development, in particular in Asia [1]. The increasing need for energy gave further consideration must be made to avoid an energy crisis. Researchers suggest renewable energy as an alternative energy source for the future, where this energy is humanity's biggest challenge in the $21^{\text {st }}$ century [2-5]. The sun is an example of a renewable energy source that is always there every day. Energy from the sun can be extracted using a device called a solar cell [6]. Solar cells are a technology that converts sunlight into electrical energy [7-12]. The main material of solar cells is a semiconductor material which is generally in the form of silicon, germanium, gallium arsenide, or compounds formed from the elements of group III and IV [13].

The amount of energy gap for each material used for solar cells is different [14]. This can be used to form a multijunction solar cell where the solar cell is composed of several layers consisting of various kinds of semiconductor materials. Semiconductor materials with a higher energy gap are placed on the top layer, while semiconductor materials with the lowest energy gap are placed on the lowest layer [14]. The benefits of making multi-junction solar cells have the aim of increasing the absorption power of solar cells which leads to an increase in the efficiency of solar cells [15]. Making surface texturing on the top layer of solar cells is very helpful to reduce the energy lost due to light reflection that occurs during the energy absorption process [16].

In theory, the efficiency of solar cells made with multi-junction structures reaches $41.6 \%$ under ideal conditions and this theoretical study is almost the same as laboratory studies [17]. A theoretical or simulated calculation is very useful prior to laboratory experiments. The PC1D program is a freeware application that can be used to simulate solar cells to obtain a high level of efficiency.

In 2013, the same study was conducted by Sobirin [14]. He has simulated triple-junction solar cell modelling using layers of $\mathrm{Al}_{0.3} \mathrm{Ga}_{0.7} \mathrm{As}$, InP, and Ge. The solar cells from Sobirin's research showed that the solar cells he simulated showed an efficiency of 38.86\% for Model 1 and 20.26\% for Model 2.

This study discusses the design simulation of triple-junction solar cells with layers of $\mathrm{Al}_{0.3} \mathrm{Ga}_{0.7} \mathrm{As}, \mathrm{GaAs}$, and $\mathrm{Ge}$ especially for Model 2 of triple-junction solar cells and the effect of adding surface texturing on cell efficiency.

\section{RESEARCH METHODS}

In the research, the triple-junction solar cell modelling simulation uses the PC1D application to find the values of $\mathrm{I}_{\mathrm{sc}}$, $\mathrm{V}_{\mathrm{oc}}$, and $\mathrm{P}_{\max }$ by adjusting the thickness and doping and the initial intensity is given $0.1367 \mathrm{~W} / \mathrm{cm}^{2}$ with a black body radiation spectrum at a temperature of $5523 \mathrm{~K}$. As well as the 
calculation of absorption using numerical calculation applications, namely MATLAB.

\section{RESULTS AND DISCUSSION}

Assuming the sun has a temperature of $6000 \mathrm{~K}$ with a wavelength of between $100 \mathrm{~nm}$ to $2500 \mathrm{~nm}$, the black body radiation emitted by the sun to the earth surface can be seen graphically in Figure 1.

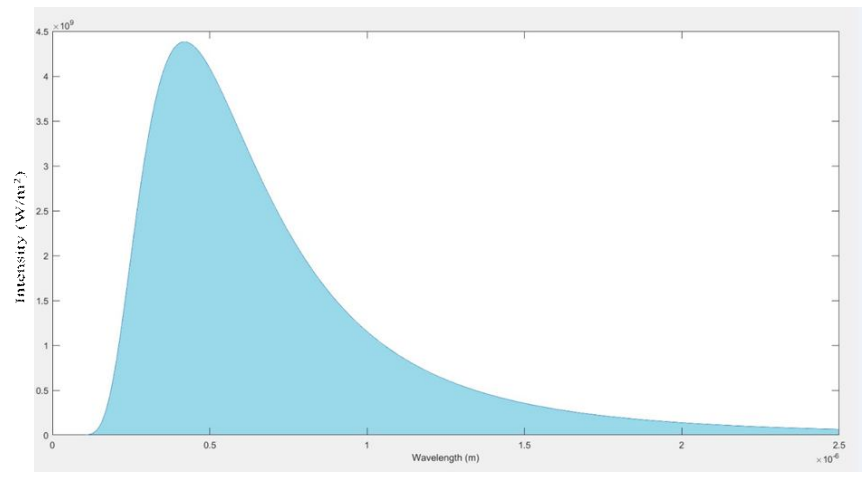

Figure 1: The spectrum of black body radiation on the earth surface

The intensity of solar radiation received by the first semiconductor $\left(\mathrm{Al}_{0.3} \mathrm{Ga}_{0.7} \mathrm{As}\right)$ is $1367 \mathrm{~W} / \mathrm{m}^{2}$ which has a thickness of $2.98 \mu \mathrm{m}$ according to Table 1 .

Table 1: Input parameters of the simulation of solar cells

\begin{tabular}{|c|c|c|c|c|c|}
\hline Layer & $\begin{array}{c}\text { Intensity } \\
\left(\mathbf{W} / \mathbf{c m}^{2}\right)\end{array}$ & $\begin{array}{c}\text { Thick } \\
(\boldsymbol{\mu m})\end{array}$ & $\begin{array}{c}\text { Wavelength } \\
(\mathbf{n m})\end{array}$ & $\begin{array}{c}\text { P Doping } \\
\left(\mathbf{c m}^{-3}\right)\end{array}$ & $\begin{array}{c}\mathbf{N} \text { Doping } \\
\left(\mathbf{c m}^{-3}\right)\end{array}$ \\
\hline $\mathrm{Al}_{0.3} \mathrm{Ga}_{0.7} \mathrm{As}$ & 0.1367 & 2.98 & $0-2500$ & $1.00 \mathrm{E}+19$ & $1.00 \mathrm{E}+20$ \\
\hline $\mathrm{GaAs}$ & 0.0523 & 4.95 & $0-2500$ & $1.00 \mathrm{E}+18$ & $1.00 \mathrm{E}+20$ \\
\hline $\mathrm{Ge}$ & 0.0249 & 5.63 & $0-2500$ & $1.00 \mathrm{E}+17$ & $1.00 \mathrm{E}+18$ \\
\hline
\end{tabular}

The optimal thickness $(2.98 \mu \mathrm{m})$ to get an outflow of 11.9 $\mathrm{mW}$, then transmit the intensity of solar radiation of 523 $\mathrm{W} / \mathrm{m}^{2}$ which will then be absorbed by the second layer, namely the GaAs layer which has a thickness of $4.95 \mu \mathrm{m}$. From the GaAs layer with these specifications, it can absorb the intensity of solar radiation of $274 \mathrm{~W} / \mathrm{m}^{2}$ and transmits 249 $\mathrm{W} / \mathrm{m}^{2}$ of solar radiation which can then be reused for the last layer with germanium $(\mathrm{Ge})$ semiconductors. The germanium layer has a thickness of $5.63 \mu \mathrm{m}$ which can absorb the intensity of solar radiation of $226 \mathrm{~W} / \mathrm{m}^{2}$ and transmits 23 $\mathrm{W} / \mathrm{m}^{2}$ to the environment. The triple-junction solar cell scheme that has been described can be seen in Figure 2.

The thickness of a semiconductor is very influential on the resulting performance. This factor comes from the intensity of solar radiation received and the energy gap of the semiconductor itself. The easiest way to improve the performance of the semiconductors used is to change the thickness. The thicker the semiconductor layer used, the smaller the energy gap required. Therefore, the thickness of the semiconductors is sorted from the smallest to the top layer [14].

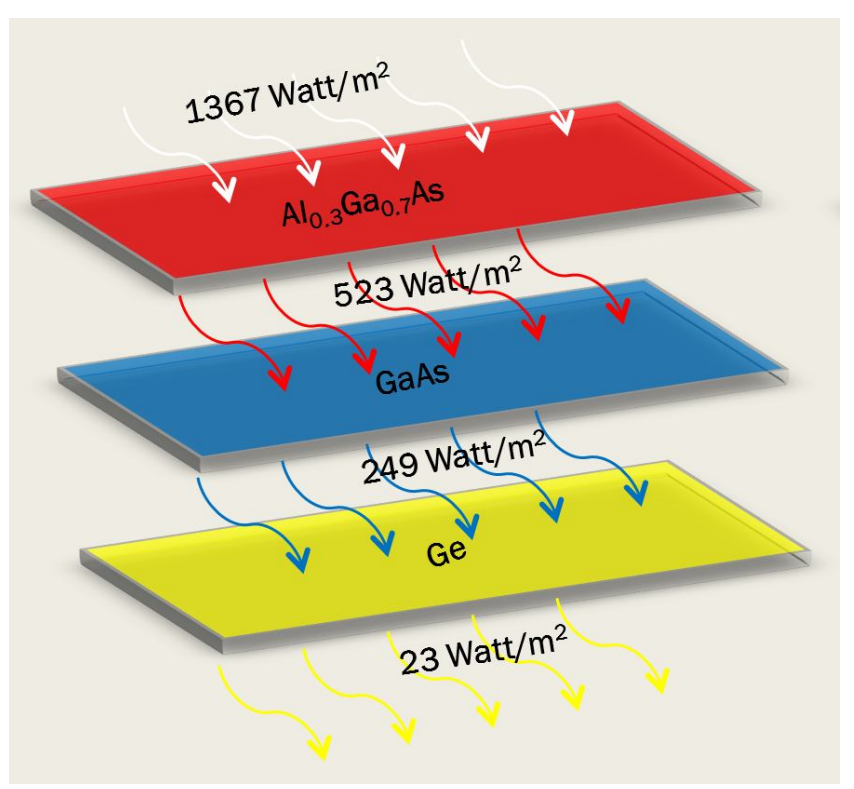

Figure 2: The simulation result of triple-junction solar cell transmission intensity

In addition to thickness, the addition of doping will greatly affect the output value that will be released from the semiconductors used due to the intensity of solar radiation. In this study, the doping value for $\mathrm{P}$ type and $\mathrm{N}$ type of each semiconductor used has the same value as the solar cell from the previous simulation as a second comparison parameter other than outflow (parameters can be seen in Table 1). The simulated solar cell schematic can be seen in the following Figure 3.

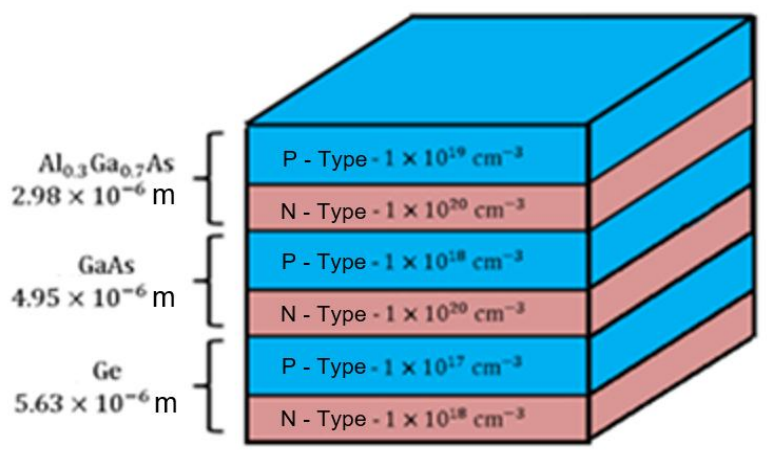

Figure 3: The simulation of triple-junction solar cell modelling

Solar cell modelling was carried out using three types of semiconductors with energy gaps arranged from the highest in the top layer to the lowest in the lowest layer. The semiconductors used consist of $\mathrm{Al}_{0.3} \mathrm{Ga}_{0.7} \mathrm{As}\left(\mathrm{E}_{\mathrm{g}}=1.8 \mathrm{eV}\right)$, GaAs $\left(E_{\mathrm{g}}=1.424 \mathrm{eV}\right)$, and $\mathrm{Ge}\left(\mathrm{E}_{\mathrm{g}}=0.667 \mathrm{eV}\right)$. 
Fitria Hidayanti et al., International Journal of Emerging Trends in Engineering Research, 8(8), August 2020, 4666 - 4670

The absorption area of sunlight energy from the three semiconductors used in the modelling is very different [14]. This happens because the energy gap possessed by each semiconductor is different from the others. Semiconductor $\mathrm{Al}_{0.3} \mathrm{Ga}_{0.7} \mathrm{As}$ is able to absorb sunlight energy ranging from a wavelength of $100 \mathrm{~nm}$ to $652 \mathrm{~nm}$. GaAs can absorb sunlight energy with a wavelength of up to $808 \mathrm{~nm}$.

The last layer $(\mathrm{Ge})$ is able to absorb sunlight energy with a wavelength of up to $1612 \mathrm{~nm}$. This statement can be seen in Figure 4. The difference in the absorption of sunlight energy from the three semiconductors used can produce a combination called a triple-junction which has the function of increasing utilization, solar energy into electrical energy [14].

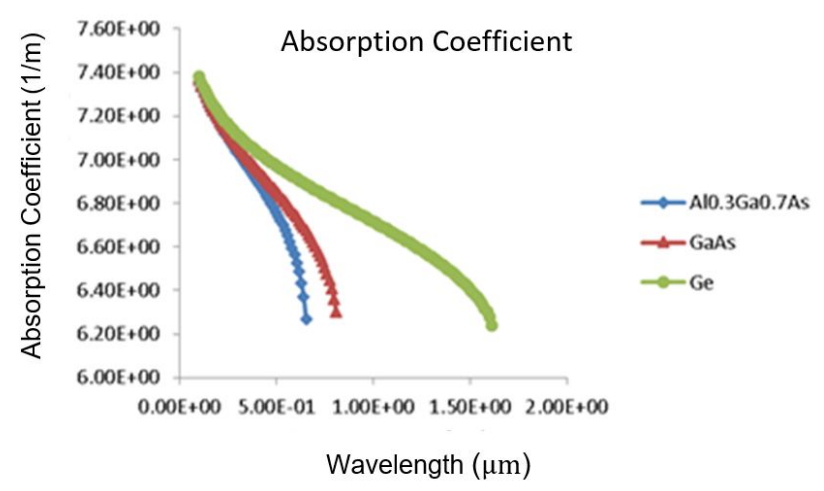

Figure 4: Absorption coefficient graphs of $\mathrm{Al}_{0.3} \mathrm{Ga}_{0.7} \mathrm{As}$, GaAs, and Ge

Then, for the energy gap of each semiconductor used is very different, the intensity of solar radiation that can be absorbed by each semiconductor will be different [14]. The $\mathrm{Al}_{0.3} \mathrm{Ga}_{0.7} \mathrm{As}$ layer is only able to absorb the intensity of solar radiation ranging from a wavelength of $100 \mathrm{~nm}$ to $698 \mathrm{~nm}$. Furthermore, the GaAs layer can absorb this radiation ranging from wavelengths of $651 \mathrm{~nm}$ to $875 \mathrm{~nm}$. Finally, the Ge layer can absorb the intensity of solar radiation with a wavelength of $852 \mathrm{~nm}$ to $1870 \mathrm{~nm}$ (Figure 5).

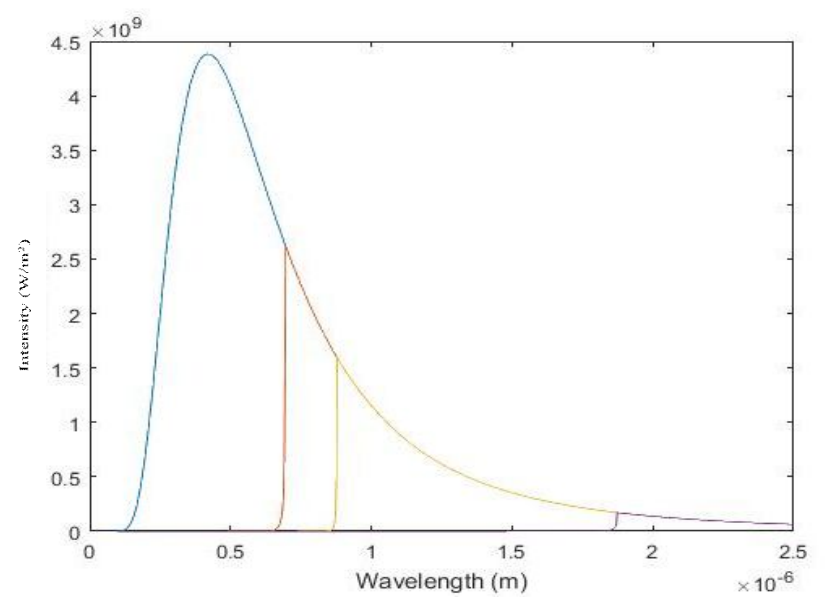

Figure 5: Absorption curves between semiconductor layers

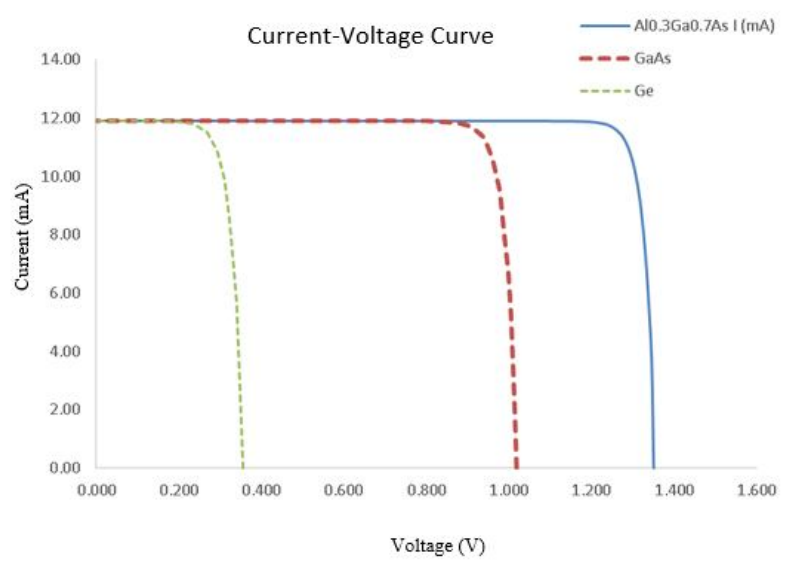

Figure 6: Current-Voltage Curve of Solar Cell

Table 2: .Solar cell simulation output parameters

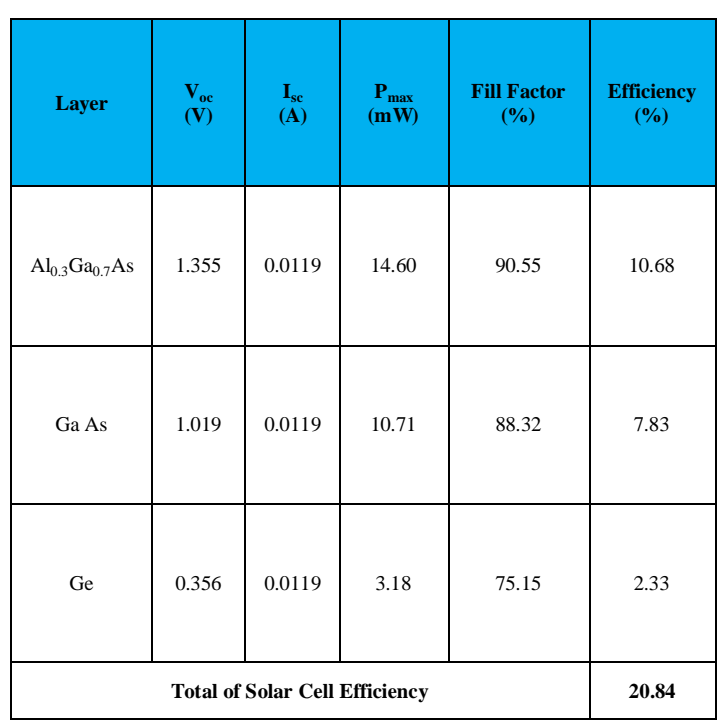

Figure 6 is a graph of the output results in the form of $\mathrm{I}_{\mathrm{sc}}, \mathrm{V}_{\mathrm{oc}}$, $\mathrm{P}_{\max }$, and IV-curve (current-voltage curve) based on the results of the research output listed in Table 2. The simulated solar cells produce $\mathrm{P}_{\max }$ for $\mathrm{Al}_{0.3} \mathrm{Ga}_{0.7} \mathrm{As}, \mathrm{GaAs}$, and $\mathrm{Ge}$, respectively of $14.6 \mathrm{~mW}, 10.71 \mathrm{~mW}$, and $3.18 \mathrm{~mW}$. Each simulated semiconductor also has individual efficiencies of $10.68 \%, 7.83 \%$, and $2.33 \%$. The total efficiency of the solar cells is $20.84 \%$. The efficiency of the triple-junction solar cell simulation results was $0.48 \%$ higher than the triple-junction solar cell produced by the study [14] with the same $\mathrm{I}_{\mathrm{sc}}$ value, namely Model 2. 


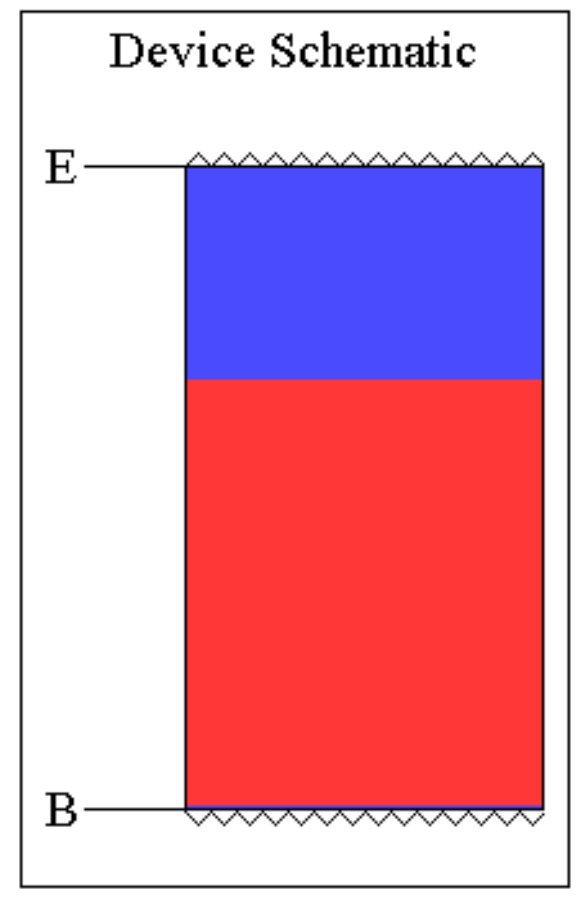

Figure 7: Surface texturing in the simulation for the type of front surface (E) and type of rear surface for layer (B).

The simulation results with surface texturing using the PC1D program produce data that are inconsistent with reality. In general, the use of surface texturing aims to improve the performance of semiconductors.

Table 3: Simulation results with the addition of a front surface type surface texturing (ST) to the first layer

\begin{tabular}{|c|c|c|c|c|}
\hline $\begin{array}{c}\text { ST } \\
\text { Thickness } \\
(\boldsymbol{\mu m})\end{array}$ & $\begin{array}{c}\text { ST } \\
\text { Angle } \\
(\mathbf{0})\end{array}$ & $\begin{array}{c}\mathbf{I}_{\text {sc }} \\
(\mathbf{A})\end{array}$ & $\begin{array}{c}\mathbf{P}_{\text {Max }} \\
(\mathbf{W})\end{array}$ & $\begin{array}{c}\mathbf{V}_{\text {oc }} \\
(\mathbf{V})\end{array}$ \\
\hline 0.001 & 15 & 0.0119 & 0.0146 & -1.355 \\
\hline 0.01 & 15 & 0.0119 & 0.0146 & -1.355 \\
\hline 0.1 & 15 & 0.0119 & 0.0146 & -1.355 \\
\hline 1 & 15 & 0.0119 & 0.0146 & -1.355 \\
\hline 0.001 & 30 & 0.0118 & 0.0145 & -1.355 \\
\hline 0.01 & 30 & 0.0118 & 0.0145 & -1.355 \\
\hline 0.1 & 30 & 0.0118 & 0.0145 & -1.355 \\
\hline 1 & 30 & 0.0117 & 0.0143 & -1.354 \\
\hline 0.001 & 45 & 0.0117 & 0.0144 & -1.355 \\
\hline 0.01 & 45 & 0.0117 & 0.0144 & -1.355 \\
\hline 0.1 & 45 & 0.0117 & 0.0143 & -1.354 \\
\hline 1 & 45 & 0.0113 & 0.0138 & -1.353 \\
\hline
\end{tabular}

Table 4: Simulation results with the addition of rear surface type surface texturing (ST) to the first layer

\begin{tabular}{|c|c|c|c|c|}
\hline $\begin{array}{c}\text { ST } \\
\text { Thickness } \\
(\boldsymbol{\mu m})\end{array}$ & $\begin{array}{c}\text { ST } \\
\text { Angle } \\
(\mathbf{(})\end{array}$ & $\begin{array}{c}\mathbf{I}_{\text {sc }} \\
(\mathbf{A})\end{array}$ & $\begin{array}{c}\mathbf{P}_{\text {Max }} \\
(\mathbf{W})\end{array}$ & $\begin{array}{c}\mathbf{V}_{\text {oc }} \\
(\mathbf{V})\end{array}$ \\
\hline 0.001 & 60 & 0.0116 & 0.0142 & -1.354 \\
\hline 0.01 & 60 & 0.0116 & 0.0142 & -1.354 \\
\hline 0.1 & 60 & 0.0114 & 0.0140 & -1.354 \\
\hline 1 & 60 & 0.0105 & 0.0129 & -1.351 \\
\hline 0.001 & 75 & 0.0133 & 0.0139 & -1.354 \\
\hline 0.01 & 75 & 0.0133 & 0.0138 & -1.353 \\
\hline 0.1 & 75 & 0.0108 & 0.0132 & -1.352 \\
\hline 1 & 75 & 0.0087 & 0.0106 & -1.346 \\
\hline
\end{tabular}

However, the simulation results show that the performance of the first layer decreases when the surface texturing parameters are added as in Table 3 for front surface type surface texturing and Table 4 for rear surface type surface texturing which has been illustrated in Figure 7. According to [14], stated that the PC1D application does not consider how much light is reflected when added with surface texturing so that the use of surface texturing in the PC1D simulation program is less effective.

\section{CONCLUSION}

Triple-junction solar cells made by semiconductors, $\mathrm{Al}_{0.3} \mathrm{Ga}_{0.7} \mathrm{As}, \mathrm{GaAs}$, and $\mathrm{Ge}$ has $0.48 \%$ higher efficiency compared to triple-junction solar cells with layers of $\mathrm{Al}_{0.3} \mathrm{Ga}_{0.7} \mathrm{As}$, InP, and Ge. This occurs because the energy gap of GaAs semiconductors is higher than that of InP semiconductors.

Surface texturing simulation using PC1D program cannot produce data that is in accordance with the theory. The theory says that the addition of surface texturing can increase the efficiency of solar cells, but the simulation results in lowering the performance of solar cells. This happened because the PC1D program during the simulation was assumed to be ideal. As a result, the use of surface texturing in the simulation is considered as additional resistance for solar cells.

\section{ACKNOWLEDGEMENT}

Thank you for Lembaga Penelitian dan Pengabdian kepada Masyarakat (LPPM) Universitas Nasioal and my colleagues at Faculty of Engineering and Science, Universitas Nasional, Jakarta, Indonesia. 


\section{REFERENCES}

1. Grubert, E. Conventional hydroelectricity and the future of energy: Linking national inventory of dams and energy information administration data to facilitate analysis of hydroelectricity. The Electricity Journal, 33(1), 106692. 2020.

2. Hidayanti F., Wati E.K., and Miftahudin M. F. Design of Energy Harvesters on Motorcycle Exhaust using Thermoelectric Generator for Power Supply Electronic Device. International Journal of Renewable Energy Research. 10(1), 251 - 259. 2020.

3. Hidayanti F., Wati E.K., and Akbar H. Energy Harvesting System Design for Converting Noise into Electrical Energy. International Journal of Advanced Science and Technology. 29(03), 4791 - 4802. 2020.

4. Hidayanti F., Rahmah F., and Wiryawan A. Design of Motorcycle Security System with Fingerprint Sensor using Arduino Uno Microcontroller. International Journal of Advanced Science and Technology. 29(05), 4374 - 4391.2020.

5. Hidayanti F., Santoso H. H., and Amalia D. Induction Measurement of Extra High Voltage Air Duct. International Journal of Emerging Trends in Engineering Research. 8(4), 1424 - 1427. 2020.

6. Bushnell, J., and Novan, K. Setting with the sun: the impacts of renewable energy on wholesale power markets (No. w24980). National Bureau of Economic Research. 2018. https://doi.org/10.3386/w24980

7. Hidayanti F., Rahmah F., and Sahro A. Mockup as Internet of Things Application for Hydroponics Plant Monitoring System. International Journal of Advanced Science and Technology. 29(05), 5157 - 5164. 2020.

8. Hidayanti F., Lestari K.R., and Anwar R. Arduino Based Conductive Silver Lamination Device. International Journal of Emerging Trends in Engineering Research. 8(2), 265 - 270. 2020.

9. Hidayanti F., Rahmah F., and Agusto J. Design of Solar Tracker on Solar Panel with Fresnel Concentrator. International Journal of Advanced Science and Technology. 29(05), 1014 - 1025. 2020.

10. Hidayanti F., Rahmah F., and Ikrimah M. Dual-Axis Solar Tracking System Efficiency for Hydroponics Pump. International Journal of Emerging Trends in Engineering Research. 8(6), 2631 - 2634. 2020. https://doi.org/10.30534/ijeter/2020/67862020

11. Hidayanti F., Performance of Portable Battery Charger of Monocrystalline Solar Panel. International Journal of Emerging Trends in Engineering Research. 8(7), 3181 - 3184. 2020. https://doi.org/10.30534/ijeter/2020/50872020

12. Hidayanti F., The Effect of Monocrystalline and Polycrystalline Material Structure on Solar Cell Performance. International Journal of Emerging Trends in Engineering Research. 8(7), 3420 - 3427. 2020.

https://doi.org/10.1007/978-0-387-29185-7
13 Kasap, S. Springer handbook of electronic and photonic materials. Springer Science \& Business Media. 2006.

14. Sobirin, R., Triple Junction Solar Cell Design Simulation of Al0.3Ga0.7As/lnP/Ge using PC1D and Matlab, Bogor: Bogor Agricultural Institute. 2013.

15. Choubey, P. C., Oudhia, A., and Dewangan, R. A review: Solar cell current scenario and future trends. Recent Research in Science and Technology, 4(8). 2012.

16. Yang, G., Guo, P., Procel, P., Limodio, G., Weeber, A., Isabella, O., and Zeman, M. High-efficiency black IBC c-Si solar cells with poly-Si as carrier-selective passivating contacts. Solar Energy Materials and Solar Cells, 186, 9-13. 2018.

17. Ezema, F. I., Ezugwu, S. C., Agbo, S. N., Ekwealor, A. B. C., Asogwa, P. U., and Osuji, R. U. 24th European Photovoltaic Solar Energy Conference. Hamburg, Germany, 295. 2009. 